\title{
APPLICATION OF QUALIMETRIC METHODS FOR EVALUATION OF URBANIZED SPACE QUALITY FOR ANALYSES OF THE LOCAL REAL PROPERTY MARKET
}

\author{
Iwona Cieślak, PhD \\ Faculty of Geodesy and Land Management \\ University of Warmia and Mazury in Olsztyn \\ e-mail: isidor@uwm.edu.pl
}

Dominika Strumiłło-Rembowska, PhD

Faculty of Geodesy and Land Management

University of Warmia and Mazury in Olsztyn

e-mail: dominika.rembowska@uwm.edu.pl

\section{Karol Szuniewicz, PhD}

Faculty of Geodesy and Land Management

University of Warmia and Mazury in Olsztyn

\begin{abstract}
An important step in understanding how the real estate market functions is the process of determining the quality of properties, which is based on the principles of selecting their identifying features. It is a difficult process often affected by errors, which result from a subjective approach and a lack of clear methods of transition from identifying features to the assessment of their quality. An interesting starting point for carrying out the assessment of space quality might be its utilitarian perception.

Urbanized space is designed to meet the needs of humans, just like industrial products. As a result of this, methods of evaluating objects for the purpose of production optimization were adapted in order to determine the quality of utilitarian space, which can also be treated as properties subjected to market transactions. Quality is the state of fulfilling a given set of requirements. It surrounds us wherever we are to affect us. Quality is the guiding principle in using or purchasing any types of goods or services. Qualimetric methods, i.e. the theory of quality, are characterized by the principles and methods of measuring quality.

The aim of this paper is an attempt to apply qualimetric methods to determine the qualities of properties which form the basis for identifying urban space. The implementation of these methods for the purpose of identifying and quantifying the state of market features can become both an important tool in determining the market value of a property and giving rise to new directions of market analysis.
\end{abstract}

Key words: property market, quality, qualimetric, utilitarian space.

JEL Classification: D12.

Citation: Cieślak I., Strumiłło-Rembowska D., Szuniewicz K., 2014, Application of qualimetric methods for evaluation of urbanized space quality for analyses of the local real property market, Real Estate Management and Valuation, vol. 22, no. 4, pp. 51-59.

DOI: $10.2478 /$ remav-2014-0036 


\section{Introduction}

Urbanized space, which is the product of human work, is meant to satisfy human needs. By organizing it, man creates a specific state of space development according to the current expectations (CIEŚLAK et al. 2013). It can thus be assumed that by developing the surrounding space, man applies the general principles of satisfying needs, which are the motivation for the production of all goods and services that create the quality of our life (CANTOR 1987). A special type of space that seems to follow this thesis is urbanized space. Our flats, which are subject to similar market principles as other goods and services, represent an example of such space. The quality of residential space that determines the level of prices noted on the real property market is a reflection of the level at which human needs are satisfied when it comes to housing. Quality, understood as the state of satisfying the formulated requirements, is the fundamental notion that became the key component to the paper.

Quality represents the core component of using or acquiring all kinds of goods or services. A common notion, considered by some to be fundamental, quality has become the subject of much scientific research (KOLMAN 1971; BORYS 1991; TRULlOls-SOlER 2006; NAZAROV, KRUSHNYAK 2006). The development of scientific thinking in this area has led to the emergence of a scientific discipline called qualitology, focusing on quality and the modelling of it (MARTínEZ 2008; MANTURA 2009; SUN 2013). According to the considerations of this discipline, quality is defined as "the complex characteristic representing a relatively homogeneous set of objects as a multidimensional space of states" (BORYS 1991).

In order to determine the quality of space, its definition as the environment of human life seems more adequate. Moreover, the assumption that the quality of usable space may be treated as an equivalent of the quality of the human life environment, understood as the set of material objects and influences taking place in that environment, seems logical. With this assumption, the state of the environment can be determined within the space of the states of quality and we call the $q_{i t}$ fulfilment of quality $F$ the quality state of the environment. This fulfilment is the multidimensional vector of the value of features describing the nature of the object - environment, i.e. (BORYS 1991):

$$
\begin{aligned}
& S \longrightarrow Q \\
& q_{i t}=F\left[x_{i t}^{(1)}, x_{i t}^{(2)}, \ldots, x_{i t}^{(m)}\right]
\end{aligned}
$$

where:

$S$ - set of objects - environments,

$Q \quad$ - space of quality states,

F - quality,

$q_{i t} \quad$ - state of quality of object $i$,

$x_{i t}^{(j)} \quad$ - state of the $j$ characteristic in the object,

$i \quad$ - identifies the spatial dimension of the object,

$t \quad$ - identifies the dynamic (time) dimension of the object.

The qualimetric approach that focuses on "measuring quality" deals with clearer and more focused studies on quality when it comes to determining it. The valuation of quality, which is nothing other than determining its level, is the basic activity of qualimetrics (STADNYK et al. 2013). However, is quality measurable? As it is known, quality is not described by any physical dimension. Still, if specific parameters that are measurable are allocated to it, we can talk about measuring quality.

Practical and theoretical knowledge on quality should be consistent. That consistency can be accomplished as a result of the quantitative determination of the states of quality, i.e. the valuation of quality. Valuation means the functional attribution of a specific value to a selected characteristic of an object. As a result, the values of the states of characteristics that correspond to their states and levels of quality are identified. The outcome of this offers the possibility of organizing the sets of elements in the listed qualitative categories according to value (KOLMAN 2009; WAWAK 2011).

Valuation of quality may also bring immense benefits in real property management. The developed qualimetric methods may facilitate the understanding of how some market mechanisms operate and improve the decision-taking process in the field of real property management.

\section{Criteria of quality}

Valuation of quality is accompanied by the notion of a quality criterion. It is certain that there is no single quality criterion describing precisely the state of the quality of a given object of analysis. Collectiveness is a characteristic of quality and hence, it must be described using sets of criteria. The 
sets of characteristics of the studied object chosen for the analysis of the state of quality comprise the so called quality criteria.

The appropriate choice of quality criteria is very important and the most difficult activity when it comes to quality analyses. When the choice is correct, we deal with efficient quality management, facilitated by quality analysis. A bad choice of criteria makes it impossible to obtain information on all the important disturbances in satisfying requirements dependant on the regulated parameters of the observed object or process.

Bardzo ważnym, co więcej najtrudniejszym działaniem w analizach jakości jest odpowiedni dobór kryteriów jakości. Gdy dobór jest prawidłowy mamy do czynienia ze skutecznym zarządzaniem jakościowym, realizowanym przy pomocy analiz jakości. Zły dobór kryteriów sprawia, że niemożliwym jest uzyskanie informacji o ważnych zakłóceniach w wypełnianiu wymagań zależnych od regulowanych parametrów obserwowanej rzeczy lub jakiegoś procesu.

Defining the set of criteria responsible for the quality of an object that is the subject of valuation is similar, to a large extent, to the process of determining the characteristics of real properties that are responsible for development of their prices. Representativeness, independence and complementarity are the basis on which they are chosen. The number of the characteristics cannot be excessively large, but their set also cannot be overly limited (KUCHARSKA-STASIAK 2006; BIŁOZOR 2013; RENIGIERBIŁOZOR, WIŚNIEWSKI 2014). The characteristics considered in the process of appraising real property value must be defined within the specific range of variability, with the value of the weight appropriate to the influence of the feature on the development of the value.

In qualimetrics, the weights responsible for the share of the individual quality criteria in the quality structure of the analyzed object are referred to as the importance of those criteria. Importance is an abstract notion. It means the urgency of satisfying the needs or intensity of the need to satisfy the requirements. It cannot be measured, thus it is dependent on many factors. Differentiating the importance of criteria within a set involves organizing them in order of decreasing or increasing importance. These correlations take place because a situation where all the factors within a large set are of the same importance is impossible.

Grading importance means allocating numbers, i.e. the importance coefficient, to the different states of characteristics. Determining the importance of the defined factors of a given set aims to represent their importance within that set. The importance of individual criteria within a set of the states of quality can be determined in different ways. One of them involves determining the level of correlation between the selected criteria and the set of universal criteria. This set was established as the group of criteria within which the overall quality of the analyzed objects is built.

Table 1

Set of universal importance criteria

\begin{tabular}{|c|c|c|c|}
\hline No. & Name & Letter symbol & The criterion carries information on \\
\hline 1 & Safety & B & protecting or posing a hazard to health or life \\
\hline 2 & Benefit & $\mathrm{L}$ & obtained benefits or outcomes \\
\hline 3 & Cost & K & costs incurred \\
\hline 4 & Reliability & $\mathrm{N}$ & $\begin{array}{l}\text { reliability, propensity for failure or operational } \\
\text { inefficiency }\end{array}$ \\
\hline 5 & Novelty & $\mathrm{C}$ & novelty, modernity, fashion or the time factor \\
\hline 6 & Efficacy & $S$ & appropriate performance of the projected tasks \\
\hline 7 & Accuracy & $\mathrm{T}$ & the intended use or consistency with the intended use \\
\hline 8 & Usability & $\mathrm{U}$ & durability, development or duration of use \\
\hline 9 & Defectiveness & W & defects, failures or that it is well made \\
\hline 10 & Looks & $\mathrm{P}$ & $\begin{array}{l}\text { on the harmony of the shape, colors, aesthetic } \\
\text { impressions }\end{array}$ \\
\hline
\end{tabular}

Source: KOLMAN 2009.

\section{Determination of the state of quality characteristics}

The quality of the analyzed object results from the state in which that object is. That state, however, must be determined as the relative state of the characteristic in order to become the subject of analysis 
concerning the numeric determination of quality. Otherwise, these states could not be summed up. The absolute states of the characteristics result from a direct measurement, have different measures or are determined by descriptive value. The relative state means the ratio of the reduced absolute value $r$, which is the absolute value decreased by the minimal value of the variability range, to the entire considered range $p$ of variability of that value, as presented by the following formula:

$$
s=r / p
$$

Based on the above, it can be concluded that: $0 \leq s \leq 1$.

This is a significant set of values based on which we determine not only the relative state of charact eristics, but also the criteria discriminants of those characteristics that reflect the relation of the state of the characteristic to the quality of the object, as well as the actual quality of the object itself. The criteri on discriminant of the characteristic whose increase in value causes an increase in the value of the obje $c t$ is equal to its relative state. In the case of a characteristic whose increase in value causes a decrease $i$ $\mathrm{n}$ the quality of the object, the criterion discriminant is equal to 1 - the relative state. A quality equal to one is the state of satisfying all the expectations referred to as complete quality. The process of transition from an absolute state, resulting from the direct observation of the characteristic to a relative state is ca lled relativization. Taking into account the nature of the analyzed object and the type of characteristics describing the quality of the object, we can apply different relativization methods. The set of the basic relativization methods includes:

- metrization;

- detailed segregation;

- rough segregation;

- graded comparison;

- alternative determination;

- conditioned evaluation;

- taxation.

Metrization is the first of the methods listed. It offers the most accurate discernment of the state of quality criteria. It is applied only in the case of quality criteria that are expressed by measurable dimensions. Since it is the most accurate method, it is also the most desirable one in the process of quality valuation. The process of metrization can be divided into stages:

- measuring the value of the considered dimension that shows its absolute state,

- computing the relative state,

- computing the criterion discriminant.

The relative state of the quality criterion is computed according to the formula:

$$
s=k_{z}-k_{i} / k_{a}-k_{i}
$$

where:

$k_{z}-$ measured value of criterion determining its current absolute state,

$k_{i}, k_{a} \quad$ - the lowest and the highest value the given criterion assumes within the range of its variability.

Detailed segregation is applied when the measurable criterion changes within the suitably wide limits of the permissible range of variability defined as the tolerance.

$$
T=k_{a}-k_{i}
$$

where:

$T$ - tolerance;

$k_{a}$ and $k_{i}$ are the highest and the lowest permissible value of the criterion.

Detailed segregation is applied when the aim of relativization is obtaining detailed knowledge on the state of the analyzed criterion within the area of its permissible variability for the purpose of quantitative determination of quality.

The method of rough segregation offers the possibility of rapidly determining the criteria discriminants representative for the ranges of the numeric values changing within the limits of tolerance. In such a case, the application of computation formulas is not required and well prepared nomograms are sufficient.

Graded comparison is based on the valuation of the state of the considered criterion according to the standard scale of states assumed earlier. The reason behind the application of such a scale is to 
facilitate decision-making in regards to the value of the relative state of the considered criterion; moreover, it significantly improves the accuracy of the evaluation of the state.

Another method is alternative determination. It involves the comparison of the actual state with the state of the applied standard, and then the issuance of an opinion on whether the formulated requirements are satisfied. Documentation or an object considered to be correct can be used as the applied standard.

Conditioned evaluation is applied for the more precise relativization of unmeasurable criteria than is offered by the ordinary estimation. In the course of the relativization process, it should be determined how many and what imperfections the given object possesses. Based on the number and intensity of the insufficiencies, the specific criterion discriminant is determined.

Taxation is the last of the listed methods. It is used for the valuation of unmeasurable characteristics that represent quality criteria. It can be said that taxation is the only method for evaluating the states of some criteria, i.e. the composition of shape and harmony of colours. The evaluator, according to his perception, is able to decide whether the state of the criterion is favourable or unfavourable (KOLMAN 2009).

In the case of evaluations aimed at determining the criteria discriminants of the characteristics of space, the methods of metrization, segregation, alternative determination and taxation prove to be the most useful. Determining the criterion discriminant for location in the case described below represents an example of applying the rough segregation method. Residential unit price variability ranges were determined for the individual register areas and, depending on the average price of these units within the given areas, the final criterion discriminant was determined.

\section{Qualitative evaluation of residential space that is the subject of purchase-sale transactions}

Within the framework of the conducted studies, an attempt was undertaken at determining the quality of residential units that were the subject of market trade within the administrative limits of the City of Olsztyn during the years 2012 and 2013. The analyzed set encompassed transaction prices of 2,164 units. For that set, the criteria discriminants of the states of characteristics were determined.

Five characteristics were identified in the studies and subjected to detailed analysis. This number resulted from the access to information on housing units sold in the real property market of Olsztyn during the time period covered. Based on the statistical analysis of the analyzed set of real property prices it was established that the transaction date had no influence on the price per $1 \mathrm{~m}^{2}$ of the unit during the studied period. Hence, the prices did not require adjustment for the passage of time.

The other analyzed characteristics were:

- location: identified based on the address data and number assigned to the registration area;

- building type: identified based on site inspection;

- floor: identified based on the data presented in the real property transactions database (City Hall of Olsztyn);

- technical state of the unit: identified based on access to appraisal documentation (of the office of property appraisers in Olsztyn).

The criteria discriminants for the listed characteristics were determined based on the analysis of the set of transactions, site inspection and survey of experts (property appraisers). The discriminants for the characteristics of building type and technical state were determined from the latter. The survey covered 30 property appraisers. For the first characteristic, they listed the shortcomings and their importance for the value in use of buildings constructed according to a defined technology. The listed shortcomings, such as the structure of the roof, lack of possibilities for modernization, were used for determining the criteria discriminants by means of conditioned evaluation. As concerns the technical state characteristic, the experts presented the method of determining this characteristic applied by them most frequently in appraisal documentation. For the characteristic of floor, the discriminants were determined based on a questionnaire based survey of a group of 62 residents in different residential neighborhoods of Olsztyn. The number of respondents that indicated the given floor as one on which they would like to reside was used to organize the criterion discriminants according to the taxation method. For the location characteristic, the criteria discriminants were defined based on the average prices of residential units recorded for the individual registration areas. The final list of the discriminants for all the characteristics has been presented in table 2. 
Table 2

Criteria discriminants for characteristics included in the analysis

\begin{tabular}{|c|c|c|c|c|c|}
\hline No. & $\begin{array}{c}\text { Descriptive } \\
\text { characteristic of } \\
\text { the unit }\end{array}$ & $\begin{array}{l}\text { Relativization } \\
\text { method }\end{array}$ & & Determination of the state & $\begin{array}{c}\text { Criterion } \\
\text { discriminant } \\
q\end{array}$ \\
\hline \multirow[t]{4}{*}{1} & \multirow[t]{4}{*}{ building type } & \multirow{4}{*}{$\begin{array}{l}\text { conditional } \\
\text { evaluation }\end{array}$} & 1 & new buildings & 0.9 \\
\hline & & & 2 & $\begin{array}{l}\text { tenement houses and other pre- } \\
\text { World War II buildings }\end{array}$ & 0.7 \\
\hline & & & 3 & $\begin{array}{l}\text { buildings of a traditional structure } \\
\text { built during the years } 1945-1990\end{array}$ & 0.5 \\
\hline & & & 4 & $\begin{array}{l}\text { buildings made of prefabricated } \\
\text { elements }\end{array}$ & 0.3 \\
\hline \multirow[t]{3}{*}{2} & \multirow[t]{3}{*}{ technical status } & \multirow[t]{3}{*}{ taxation } & 1 & very good & 0.9 \\
\hline & & & 2 & moderate & 0.5 \\
\hline & & & 3 & bad & 0.3 \\
\hline \multirow[t]{8}{*}{3} & \multirow[t]{8}{*}{ location } & \multirow[t]{8}{*}{ rough segregation } & 1 & area: 116 & 1.0 \\
\hline & & & 2 & area: $31,70,57,110,22,16$ & 0.7 \\
\hline & & & 3 & $\begin{array}{l}\text { area: } 64,28,15,63,72,92,68,160,33, \\
97,127,112,156,126,14,56,105,106, \\
104,29,67,141,125\end{array}$ & 0.6 \\
\hline & & & 4 & $\begin{array}{l}\text { area: } 21,98,90,74,23,153,86,20,109, \\
73,155,17\end{array}$ & 0.5 \\
\hline & & & 5 & $\begin{array}{l}\text { area: } 61,66,91,75,115,60,118,19,62, \\
161,27,108,71,69\end{array}$ & 0.4 \\
\hline & & & 6 & area: $25,6,139$ & 0.3 \\
\hline & & & 7 & area: 77,102 & 0.2 \\
\hline & & & 8 & area: 6,159 & 0.1 \\
\hline \multirow[t]{5}{*}{4} & \multirow[t]{5}{*}{ floor } & \multirow[t]{5}{*}{ taxation } & 1 & floor: 2,3 & 0.9 \\
\hline & & & 2 & floor: 1 & 0.7 \\
\hline & & & 3 & floor: 4 & 0.5 \\
\hline & & & 4 & floor: 5 & 0.3 \\
\hline & & & 5 & floor: 6 and higher & 0.1 \\
\hline
\end{tabular}

Source: Own work.

Describing the relation occurring between the characteristics presented in table 2 and the universal importance criteria (tab. 1), described as ten universal quality discriminants, was the next stage of the conducted studies. The poll survey was applied at this stage to make the study credible and to decrease the level of subjective evaluation. The questionnaire was completed by 30 persons working in the real property market (property appraisers, employees of real estate agencies). The respondents considered the level of correlation between the given characteristics and the universal criteria. The correlation of characteristics was given within the range of the integers $\langle 0-5\rangle$, where 0 means no correlation and 5 means a very strong correlation. This correlation allows weights to be allocated to the characteristics chosen for analysis according to the strength with which they influence the final level of quality. This weight was described as the gravity force $p_{i}$. The results of the survey were analyzed, rejecting two questionnaires that were completed incorrectly. Next, the average value of the correlation $\left(p_{i}\right)$ was determined for the individual characteristics and presented as a set of integers. Those averaged integers were assumed as the level of correlation between the characteristics and the universal importance criteria $\left(p_{i}\right)$. The results of the procedure have been presented in table 3 . The next step involved summing up all of the obtained values and organizing them by determining their ranks $\left(L_{i}\right)$ for each of the ten universal criteria. If the totalled $p_{i}$ values were the same for a number of characteristics, then priority was given to the more important criterion, based on the opinions of previously surveyed persons. The highest criterion ranking number is 10 and decreases down to a minimum of 1 . After compiling and analyzing the specific scores allocated by the respondents, all the information was tabulated (tab. 3). 
Table 3

Level of dependence of characteristics relative to the universal quality criteria

Features

Quality criteria

\begin{tabular}{lcccccccccc}
\hline & B & L & K & N & C & S & T & U & W & P \\
\hline building type & 4 & 3 & 2 & 2 & 4 & 1 & 2 & 1 & 2 & 3 \\
\hline $\begin{array}{l}\text { technical } \\
\text { condition }\end{array}$ & 5 & 5 & 5 & 5 & 5 & 5 & 3 & 3 & 5 & 5 \\
\hline floor & 4 & 3 & 2 & 2 & 1 & 2 & 1 & 2 & 3 & 0 \\
\hline location & 5 & 5 & 4 & 3 & 4 & 4 & 4 & 3 & 4 & 3 \\
\hline \multicolumn{1}{c}{ Sum } & $\mathbf{1 8}$ & $\mathbf{1 6}$ & $\mathbf{1 3}$ & $\mathbf{1 2}$ & $\mathbf{1 4}$ & $\mathbf{1 2}$ & $\mathbf{1 0}$ & $\mathbf{9}$ & $\mathbf{1 4}$ & $\mathbf{1 1}$ \\
\hline \multicolumn{1}{c}{$L i$} & 10 & 9 & 6 & 4 & 8 & 5 & 2 & 1 & 7 & 3 \\
\hline
\end{tabular}

Source: Own work.

A further stage of work involved the organization of the criteria in relation to the number of residential units. Each level of correlation obtained was multiplied by the value obtained by the given location. The products of specific characteristics were added together and their rank of importance $\left(k_{i}\right)$ was determined by applying the formula:

$$
k_{j}=\frac{\sum_{i=1}^{10} L_{i} p_{i j}}{\min L_{i} p_{i j}}
$$

where:

$i \quad$ - number of quality criterion,

$j \quad$ - number of features of residential properties considered; $j=1,2,3,4$.

Table 4

Level of importance of characteristics

\begin{tabular}{|c|c|c|c|c|c|c|c|c|c|c|c|c|}
\hline $\begin{array}{l}\text { Quality } \\
\text { criteria }\end{array}$ & B & $\mathrm{L}$ & $\mathrm{C}$ & $\mathrm{W}$ & K & $S$ & $\mathrm{~N}$ & $\mathrm{P}$ & $\mathrm{T}$ & $\mathrm{U}$ & $\sum_{i=1}^{10} L_{i} p_{i j}$ & $k_{j}$ \\
\hline$L_{i}$ & 10 & 9 & 8 & 7 & 6 & 5 & 4 & 3 & 2 & 1 & & \\
\hline building type & 40 & 27 & 32 & 14 & 12 & 5 & 8 & 9 & 4 & 1 & 152 & 1.10 \\
\hline technical condition & 50 & 45 & 40 & 35 & 30 & 25 & 20 & 15 & 6 & 3 & 269 & 1.95 \\
\hline floor & 40 & 27 & 16 & 21 & 12 & 10 & 8 & 0 & 2 & 2 & 138 & 1.00 \\
\hline location & 50 & 45 & 32 & 28 & 24 & 20 & 12 & 9 & 8 & 3 & 231 & 1.67 \\
\hline
\end{tabular}

Source: Own work.

Determination of the quality levels of the individual units computed as the quotient of the sums of products of the values $k_{j} q_{j}$ divided by the sum of $k_{j}$ was the next step:

$$
Q_{l}=\frac{\sum_{j=1}^{4} k_{j} q_{j l}}{\sum_{j=1}^{4} k_{j}}
$$

where:

$l \quad$ - housing unit number.

This stage required the evaluation of the housing units from the perspective of the characteristics assumed for the analysis. Quality valuation was conducted on 157 transactions of housing units located in different areas of the city and representing different states of the analyzed characteristics. The number of transactions chosen for analysis resulted from the possibility of defining the characteristics of individual units.

The value of the obtained qualities $Q_{l}$ was subjected to the analysis of correlations with the 
transaction prices per $1 \mathrm{~m}^{2}$ of the corresponding units. Pearson's correlation coefficient was 0.68 and showed a high dependence of the two data items on each other (table 5).

Table 5

The results of Pearson's correlation analysis between the price and quality $\mathrm{Q}$ of residential properties

\begin{tabular}{ccccc}
\hline & average & $\begin{array}{c}\text { standard } \\
\text { deviation }\end{array}$ & price & $Q$ \\
\hline price & 0.57 & 0.1234 & 1.000 & 0.685 \\
\hline$Q$ & 0.49 & 0.0869 & 0.685 & 1.000 \\
\hline
\end{tabular}

Source: Own work.

Figure 1 serves as a graphic representation of that correlation, with the graph showing the spread for the $\mathrm{Q}$ and price variables (standardized value), the distribution of variables and descriptive characteristics.
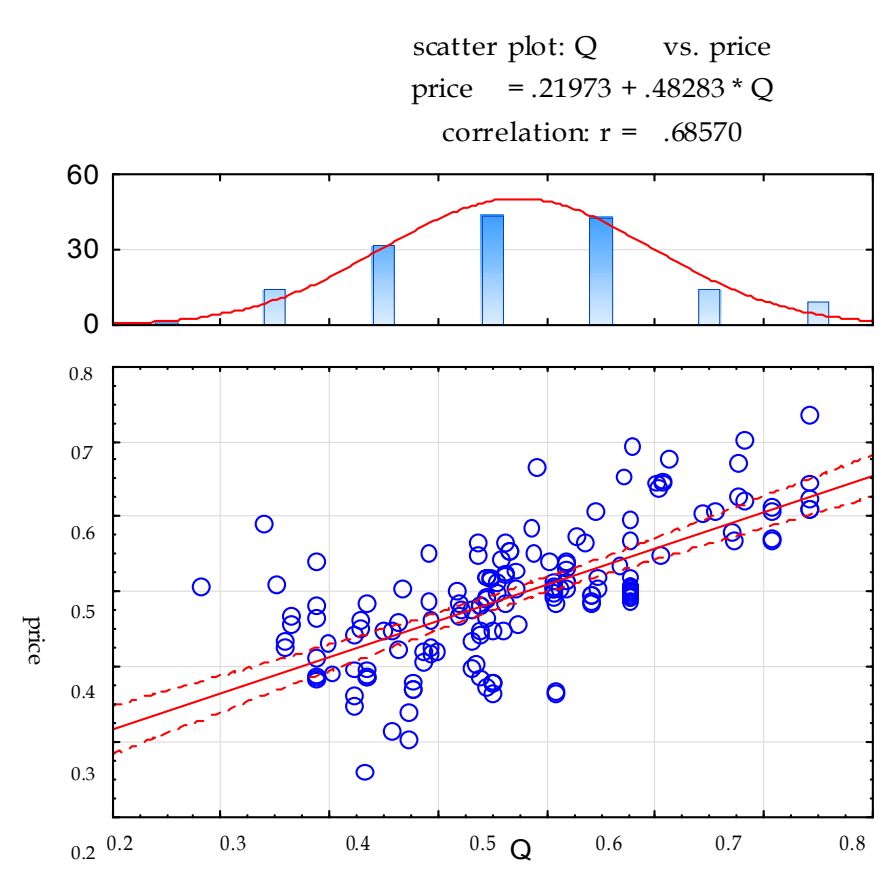

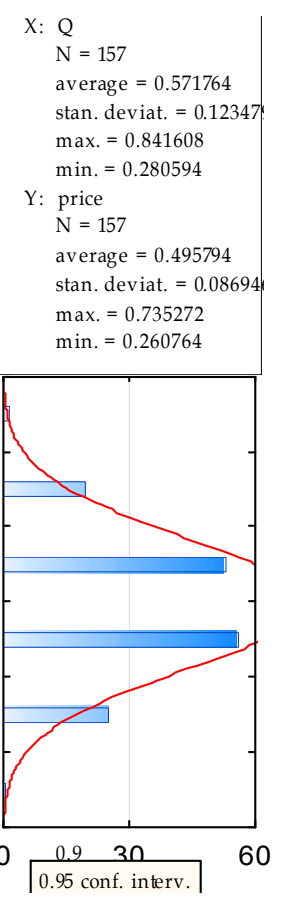

Fig. 1. Graphic representation of the correlation between the quality $Q$ and standardized prices of housing units that occurred in the real property market of Olsztyn in 2012 - 2013. Source: own study.

Hence it was proven that qualitative valuation methods may be successfully applied to determine the quality of usable space, and that the results of qualitative valuation related to such objects may be considered when studying correlations taking place in the real property market.

\section{Discussion of results and conclusions}

The conducted analyses investigated the suitability of qualimetric methods for the quantitative determination of the quality of housing units that are subject to market trade. The main objective of the studies was to determine the correlations between quality determined in such a way and the prices of units. The existence of such a correlation would allow us to draw conclusions regarding the suitability of qualimetric methods for the identification of regularities taking place within the framework of the real property market.

The conducted studies proved the existence of such a correlation. A set of 2,164 transactions that had taken place on the real property market in Olsztyn during the years 2012-2013 was subjected to studies aiming to determine the principles of qualitative valuation. The analysis of this set served to determine the characteristics identifying the quality of the housing units within it, and was also the base for establishing criteria discriminators for some of those characteristics. It should be highlighted, however, that the database of transactions used contained very limited descriptions of the units, in 
particular as concerns characteristics that could be significant for the studies. These characteristics include the technical state of the unit and building construction technology, as well as the description of the neighbourhood or aesthetic characteristics. The analysis was supported by surveys and site inspection aiming to expand the scope of information.

Finally, the existence of correlations between the determined quality $Q$ and the prices of the housing units was confirmed. The existence of such a correlation is proven by Pearson's correlation coefficient obtained for the two analyzed values. This coefficient was determined as 0.68 , which should be considered high given the nature of the objects under study. The quality of analytical results is based mainly on two analytical characteristics: precision (accuracy) and representativeness (VeredaAlonso 1999). Both of those characteristics are difficult to define precisely for spatial data. In the case of identifying the characteristics of real properties determining the quality of these objects both the accuracy and representativeness of the data are largely blurred. This is due to the limited access to information on qualitative characteristics, as well as the wide set of these characteristics and necessity of selecting them.

The developed usable space valuation procedure may be modified depending on the needs and purpose of the analysis, as well as the nature of the valuated objects. It seems necessary to work on improving it and making it more efficient, for instance as concerns obtaining qualitative characteristics and their valuation. Still, it should be highlighted that the application of qualimetric methods offers the possibility of improving market analyses, in terms of identifying both the rules of how real estate trade operates as well as developer processes. That method makes it possible to obtain a higher level of objectivism in the qualitative evaluation of characteristics as well as the simple identification of their significance to quality.

\section{References}

BıŁOZOR A., 2013, Development of a Decision-Making Algorithm for Determination of the Optimal Land Use Function, Real Estate Management and Valuation, No. 21(3), pp: 15-24.

BoRYS T., 1991, Kwalimetria. Teoria i zastosowanie, Wydawnictwo Akademia ekonomiczna w Krakowie Instytut Towaroznawstwa, Kraków.

CANTOR N., Norem J.K., Niedenthal P.M. , LANGSTON C.A., 1987, Life Tasks, Self- Concept Ideals, and Cognitive. Strategies in a Life Transition, Journal of Personality and Social Psychology, No. 53(6), pp:1178-1191.

CieŚLAK I., SZUNIEWICZ K., GERUS-GOŚCIEWSKA M., 2013, Evaluation of the Natural Value of Land Before and after Planning Procedures, Rural Development, No. 6(3), Aleksandras Stulginskis University, Akademija, Kaunas district, Lithuania.

Hamrol A., MANTURA W., 2009, Zarządzanie jakością. Teoria i praktyka, Wydawnictwo Naukowe PWN, Warszawa.

KolmAN R., 1971, Qualitology - science of quality mechanik, Miesięcznik naukowo-techniczny, No.44(8), pp: 457-\&.

KOLMAN R., 2009, Kwalitologia, Wydawnictwo PLACET, Warszawa.

KUCHARSKA-STASIAK E., 2006, Nieruchomość w gospodarce rynkowej, Wydawnictwo Naukowe PWN.

MARTínEZ P. 2008. Qualitology. Unlocking the Secrets of Qualitative Research. ESIC.

NAZAROV N.G., KRUSHNYAK N.T., 2006, What is measured in qualimetry?, Measurement Techniques, No: 49(3), pp: 238-243.

RENIGIER-BIŁOZOR M., WIŚNIEWSKI R., 2014. Real estate market rating - need or necessity?, Real Estate Management and Valuation, No. 21(4), pp: 54-64.

STADNYK B., MOTALO V., 2013, Evaluation of Qualimetrical Measurements Quality Based on the Uncertainty Concept, PAK, No. 59, pp: 950.

SUN G., LIANG R., Wu F., QU H., 2013, A Web-based visual analytics system for real estate data, Information Sciences, No. 56(5), pp: 2.

TRULlOls-SOlER E. 2006. Validation of Qualitative Analytical Methods. Doctoral thesis. Universitat Rovira I Virgili.

VeredA-AlOnso E., PE’REZ-HidAlgo J.A., R’IOs A., VAlCA`RCEL M., 1999, Computer-assisted qualimetric optimization of analytical methods, Chemometrics and Intelligent Laboratory Systems 48(1999), pp: 81.

WAWAK S. 2011. Zarządzanie jakościq - podstawy, systemy i narzędzia. ONEPRESS. 